\title{
MANAGING DEVELOPMENT OF EVENT TOURISM OFFER BASED ON NON-MATERIAL HERITAGE: CASE STUDY RIJEKA CARNIVAL
}

\author{
Danijel Drpić \\ Zrinka Zadel \\ Merdžana Obralić
}

https://doi.org/10.20867/tosee.05.40

\begin{abstract}
Purpose - To explore possibilities for improvement of the existing tourist offer of the city of Rijeka on the example of the event Rijeka Carnival. Event managing must be focused on creating the additional value of tourist offer. Due to its characteristics, Rijeka Carnival enables the formation of a new and innovative model of managing tourist product based on heritage, it improves the level of satisfaction and level of competitiveness on the tourist market.

Methodology - Managing the development and determining strategic guidelines of development of Rijeka Carnival will be created based on the research of attitudes and satisfaction of its visitors, and by studying available scientific literature. The research was conducted using a structured questionnaire during the Rijeka Carnival in 2016. The authors will use the following scientific methods: statistical methods, historical method, the method of induction and deduction, the method of conclusion, desk-research, and others.

Findings - Rijeka Carnival is the most famous tourist event of this sort in Croatia, and it possesses numerous insufficiently used developmental possibilities. In order to improve the existing offer of Rijeka Carnival, it is mandatory to determine the habits, desires, and level of satisfaction of Carnival visitors, and based on the finding make a new developmental strategy.

Contribution - The paper provides guidelines for the destination management for improvement of the existing event managing model. Based on the research results destination management will be able to manage more efficiently the Rijeka Carnival tourist offer in a way to remove possible threats for life-cycle of a tourist event

Keywords Events, Event managing, non-material heritage, Rijeka Carnival
\end{abstract}

\section{INTRODUCTION}

Each tourism product/event based on the heritage must derive from the adopted development strategies of the tourist destination in order to contribute to its realization by organizing the event, which will contribute to the growth of the destination competitiveness on the tourist market. While organizing an event, the tourist demand for heritage-based events should be taken into consideration, as well as the possibilities of meeting the needs and wishes of modern visitors in the most appropriate way. Heritagebased tourism events (and especially those based on non-material heritage) contribute to the success and recognition of the tourist destination on the market and directly affect its competitiveness. The competitive positioning of the tourist destination is conditioned by the diversity of the tourist offer, which must be of higher quality in regards to the environment and based on the TQM postulates (Drpić 2017). 
ToSEE - Tourism in Southern and Eastern Europe, Vol. 5, pp. 249-262, 2019

D. Drpić, Z. Zadel, M. Obralić: MANAGING DEVELOPMENT OF EVENT TOURISM OFFER BASED ...

Particular attention needs to be focused on ensuring sustainable managing of a tourist event based on non-material heritage due to its sensitivity on social changes stimulated by global movements on the tourist market, and migrations of the population. Within the paper the authors present Rijeka Carnival as an example of preservation of Kvarner's and Croatian Adriatic's non-material heritage. Based on determining the level of satisfaction of the respondents with the tourist offer within the event conclusions are made and model for improvement and standardizing of tourist event offer is determined, which bases its originality and elements of offer on preservation and improvement of non-material heritage as an important element of population's local identity.

The paper consists of the following: after the introduction, in the first chapter titled Competitiveness of Tourist Events based on the Non-Material Heritage-a Theoretical Background the authors present the newest findings of the researches that were focused on events based on non-material heritage and its contribution towards achieving competitiveness on the tourist market. The second chapter titled Rijeka Carnival in the Function of Attaining the Competitive Advantages of the City of Rijeka the basic characteristics about Rijeka Carnival are presented and how does this event contribute to higher competitiveness of Rijeka as a tourist destination. Within the third chapter Methodology the authors presented the structure of the questionnaire and the methodology based on which it was developed, and the applied statistical methods. In fourth chapter, titled Findings the authors presented the results of the empirical research. Fifth chapter carries the title Model of the Successful Tourist Events based on Heritage in which the authors presented the proposal of a developmental model focused towards further development of event tourist offer and increasing the level of satisfaction of event visitors. Finally, conclusion remarks were given based on the determined results.

\section{COMPETITIVENESS OF TOURIST EVENTS BASED ON THE NON- MATERIAL HERITAGE-A THEORETICAL BACKGROUND}

Competitiveness in the modern market environment represents the basis for the survival of a product or a company. Thus, competitiveness includes the potential to develop into the core competitiveness and competitive advantage (Milohnić 2012; Evans at all 2003). Knowledge can be determined as the core competitiveness of the 21 st century, and therefore, while considering competitiveness and retaining (gaining) a leading position in the tourism market, a lot of attention is paid to the acquisition of new knowledge and skills and the application of modern technological solutions. Many authors agree that knowledge enables the successful creation of new innovative and unique products, meanwhile creating a new higher value for its users and achieving a sustainable competitive advantage (Senge 2001; Teece et al. 1997).

Competitive advantages appear to be the response to the question: How to improve your position in regards to competition in the future? The sources of competitive advantage are found in the combination and application of skills and the development of superior resources in creating value for the guest. Thus, resources can be divided into material and non-material. The attractiveness of the destination and the tourist event depends on the fundamental resource base, the facilitating factors, the destination management and 
ToSEE - Tourism in Southern and Eastern Europe, Vol. 5, pp. 249-262, 2019

D. Drpić, Z. Zadel, M. Obralić: MANAGING DEVELOPMENT OF EVENT TOURISM OFFER BASED ...

qualitative determinants (Milohnić 2012; Hall 1997; Crouch 2011; Porter 1990; OECD 2009).

Non-material heritage represents an inevitable part of a contemporary tourist product on world level, and it has become an object of many researches. Many definitions were developed in order to improve its understanding. One of the most used ones is the one by UNESCO (2013) which defines non-material heritage as a combination of practices, statements, knowledge, skills-as well as tools, objects, artefacts and culturalspaces which the local community, groups and in some cases the individual, recognoze as a part of their cultural heritage.

Non-material heritage can justifiably be considered as an "identification card" of a certain place or a region, and its preservation stimulates those particularities that enable differentiation in relation to the other world destinations (Drpić et al. 2017).

Successful synergy of tourism and non-material heritage will impact the creation of a more recognizable destination and the growth of its competitiveness on the market. The competitiveness of tourist events is conditioned by the quality and diversity of the offer of events. The quality of the offer must be at a level that significantly exceeds the expectations of users since the success of a product can be determined by its ability to meet the needs and demands of the user. The competitiveness of the destination is also conditioned by the level of non-material heritage representation in a tourist product (thematic events, exhibitions, concerts), which encourages raising the awareness of the local community about its own identity, which is being presented in the market thanks to the event, while the tourist event becomes the place of meeting different cultural identities and customs. The successful merging of different cultural influences will positively influence the growth of the competitiveness of the destination for the reason this will attract a large number of visitors whose satisfaction will grow due to the sense of belonging and acceptance in the destination. The satisfaction of visitors of a touristic event and destination is reached thanks to the innovation, quality, creativity, consistency, and thoroughness of the destination management, as well as all others involved in the destination, who work on designing a heritage-based event. In order to maintain and improve the competitive advantage, it is necessary to permanently upgrade the existing offer with new elements, using modern knowledge and skills, as well as information technology. The competitiveness will also be significantly affected by the financial sustainability of heritage-based tourism events. It will have a positive impact on increasing the quality of the tourist offer as an indispensable element for achieving the competitiveness of the tourist destination. It is the tourist events that are a significant element of the competitiveness of tourist destinations because of their specialty and uniqueness (Ivančić 2015; Cibinskiene 2012; Jelinčić 2009; Jelinčić 2012).

Getz points out that the events are a significant motivator for the arrival of tourists in a particular tourist destination and as such have a significant role in strategic and marketing plans in many destinations, meanwhile the planning of events has become fundamental for improving the competitiveness of the tourist destination. Getz further points out that besides the fact that the research on events is carried out by professionals in the field in the last few decades, the events also became the interest of the scientific community (Getz 2008; Getz and Page 2015; Drpić 2017). 
Figure 1: Model of successful heritage-based tourism events

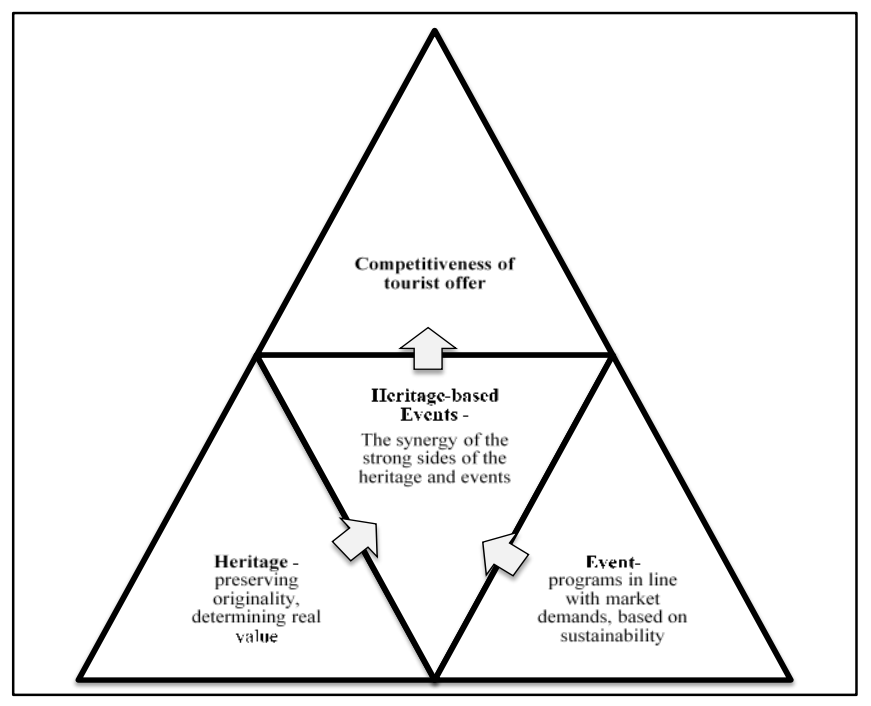

Source: Drpić (2017)

Figure 1 indicates that for the competitiveness of a tourist offer, based on heritage-based tourism events, it is necessary to establish a sustainable synergy between the components of the offer: heritage and events. Non-material heritage, which represents the backbone for the creation of a unique tourist product, points to the identity of the people and destination, and through measurable indicators becomes a credible element of the competitiveness of the destination. Heritage management is a challenge of high value for the Destination Management since it determines the modalities and the level of heritage presence in a tourist product. The decision on the issue must be made in accordance with all the involved in the destination, for example, businessmen of the scientific and professional community, the local community and others. Heritage can be an integral part of a tourist product only if it is managed on the principles of sustainability, respecting its carrying capacity, and by creating programs through which the additional social, economic and cultural value of the heritage is created (Zadel and Bogdan 2013; Drpić 2017; Knešaurek and Carić 2018).

On the other hand, the event using contemporary scientific knowledge on planning and managing the event contributes to the creation of complete harmony of non-material heritage and tourism. The event itself becomes an integral part of local awareness community and part of the heritage, and part of the local identity. In order to manage it, the local community should also be involved in the development of a tourist event in all stages of development in order to be a part of the new event from the first moment. One of the most important Croatian events that became recognized worldwide is Rijeka Carnival, due to the inclusion of elements of non-material heritage of Primorje in its offer. In the following chapter the authors will present its importance as a part of Croatian tourist product. 
ToSEE - Tourism in Southern and Eastern Europe, Vol. 5, pp. 249-262, 2019

D. Drpić, Z. Zadel, M. Obralić: MANAGING DEVELOPMENT OF EVENT TOURISM OFFER BASED ...

\section{RIJEKA CARNIVAL IN THE FUNCTION OF ATTAINING THE COMPETITIVE ADVANTAGES OF THE CITY OF RIJEKA}

Carnival is the time of the year when people forget about their life's difficulties and smoothly, using a mask become someone else, but also indicate all the problems and imperfections of the society in which they live, whose source can be found in old Romanesque rituals and customs, and they are popular all around the world (Lozica 1997). Carnivals are of great importance in the tourist offer of events in the world, and some of the most famous carnivals organized around the world are i.e. in Rio de Janeiro, Mardi Gras in New Orleans and Venice. It is important to mention that the Association of European Carnival Cities FECC operates in Europe. According to its features, the Rijeka Carnival belongs to the Mediterranean Carnival, and the Croatian Tourist Board enlisted Rijeka Carnival among the top events in Croatia (Nakovski et al. 2015).

The Rijeka Carnival is a tourist event based on the traditional immaterial heritage, and it is related to the time of carnival, when, according to old beliefs, masks and terrible mythological beings and allegory horses coerced winter and all the evil that it brings. The Rijeka Carnival is an event that in one place connects the past and the present of the coastal region in a visible way, and it represents a powerful element which provides clearly the identity of the coast and the city of Rijeka in the tourist market (Stipanović et al. 2015; Rijeka Tourist Board 2018).

The Republic of Croatia, as well as numerous other European countries, binds its carnival with Old Slavic customs, church rituals or foreign powers who ruled there over the centuries. The greatest intensity of masquerade celebrations in our country is recorded on the coast and Istra, Međimurje and Zagorje. The Rijeka Carnival in its essence today is a significant element of the cultural heritage of the Republic of Croatia, and it represents a strong and recognizable touristic product of the city of Rijeka. The Rijeka Carnival connects the urban and rural part. Urban hustle and bustle of the city together with the rural environment is observed in "Zvončari" or Bell-Ringers, which preserve the traditional village mezzanine event and keep it from the oblivion.

Only two elements of the carnival can fully reflect today's Rijeka Carnival, which only as such can be recognized as a successful tourist product. Over the last three decades, a significant increase in the popularity of the Rijeka Carnival is evident. The number of visitors and participants is constantly increasing, and the program is getting richer and more diverse. This was confirmed by the acceptance of Rijeka as the full member of Federation European Carnival Cities (FECC) in 1995 (Rijeka Tourist Board 2013). The Rijeka Carnival is famous for its two important carnival parades: the children's parade and the main carnival procession. The children's parade consists of between 4,500 and 6,000 participants in 61-76 carnival groups. The main carnival procession consists of between 8,000 and 10,100 participants and 94-117 carnival groups. The main carnival parade is an allegorical chariot. Their number ranges from 70 to 81 (Rijeka Tourist Board 2019).

The assessment of the number of participants makes it difficult to make the appropriate conclusions and guidelines of a tourist event. Organizers should create a way for more accurate statistical tracking of the number of visitors, for example, requesting a 
ToSEE - Tourism in Southern and Eastern Europe, Vol. 5, pp. 249-262, 2019

D. Drpić, Z. Zadel, M. Obralić: MANAGING DEVELOPMENT OF EVENT TOURISM OFFER BASED ...

mandatory online application or through a dedicated web/mobile application. This would enable easier and continuous monitoring of the satisfaction of visitors and participants of the carnival, and provide the possibility of a quick reaction to all observed shortcomings.

\section{METHODOLOGY}

The authors undertook an empirical research with the primary data in which they used a structured questionnaire which was translated and offered in Croatian and English language to the participants who attended the event and who voluntarily agreed to participate in the research when asked. No difficulties occurred during the gathering of data. The questionnaire consisted of six parts, first being determining the sociodemographic characteristics of the respondents, after which followed determining the motive of arrival to a destination and visiting the event, way of informing prior arrival to the destination, their way of arrival to the destination, their level of satisfaction with the elements of the offer. Likert Scale was used for determining the level of satisfaction $(-5$ disappointed; -4 very dissatisfied; -3 dissatisfied; -2 slightly dissatisfied; -1 more dissatisfied than satisfied; 0 Not satisfied or satisfied; 1 I am slightly satisfied; 2 more satisfied than dissatisfied; 3 satisfied; 4 very satisfied and 5 Enthusiastic). The questions were prepared according to the methodologies of previously undertaken researches such as TOMAS 2009, Guidelines Survey procedures for Tourism Economic Impact Assessment of Gated Events and Festivals (Ontario Ministry of Tourism 2007), and Getz (2010) in order to determine the necessity to know the socio-demographic characteristics of visitors as the basic element for creating a successful event. The main goal is to investigate the importance of satisfaction of Rijeka carnival visitors and to find out what are the characteristics of the users of the Rijeka Carnival service, in order to develop guidelines for further improvement of the tourist offer and, therefore, a more competitive position of the city of Rijeka on the tourist market. The following hypotheses were formed within this study:

H1. Rijeka Carnival visitors have different social-demographic characteristics.

H2. Visitors to the Rijeka Carnival are very satisfied with the event visit.

H3. Visitors to the Rijeka Carnival receive the most information about the tourist event from the Internet and other modern technologies.

The previously presented hypothesis were tested with the use of SPSS 2.0 Program, and Arithmetic Mean and Standard Deviation, and Pearson's Coefficient of Correlation were applied.

\section{THE RESULTS}

The data gathered from the survey conducted during Rijeka's Carnival on February 7 , 2016, indicated that there were 351 respondents. $41.6 \%$ of them being male, and $58.4 \%$ female. The average age of the respondents was 38.17 years, with a standard deviation of 11.881 years. The youngest respondent was 17 and the oldest was 65 years old. In regards to the level of formal education, $45.9 \%$ of the respondents had a secondary 
ToSEE - Tourism in Southern and Eastern Europe, Vol. 5, pp. 249-262, 2019

D. Drpić, Z. Zadel, M. Obralić: MANAGING DEVELOPMENT OF EVENT TOURISM OFFER BASED ...

education degree, $44.7 \%$ of the respondents had the faculty degree, while $9.4 \%$ of the respondents stated that they were Ph.D. holders. According to the state of permanent residence, the majority of respondents are from the Republic of Croatia $(40.2 \%)$, followed by Slovenia (26.5\%), and Germany (15.7\%). Just over half of the respondents, $58.4 \%$ of them attended the carnival for the first time at the Rijeka Carnival, $16.8 \%$ twice, $2.0 \%$ three times, $0.3 \%$ four times, and even $14.0 \%$ five and $8.5 \% 6$ times. The largest number of respondents during the Rijeka Carnival stayed in the hotel (39\%), $16.8 \%$ in a private accommodation and $12.5 \%$ in a hostel, while $31.6 \%$ of respondents stated that they stayed with at a friend/acquaintance's home. The aforementioned has confirmed the $\mathrm{H} 1$ on the heterogeneity of tourist demand at the Rijeka Carnival, which points to the need for improvement of existing models of events promotion, the introduction of new programs intended for all age groups, and the inclusion of all age and educational groups of citizens in the tourist product Rijeka Carnival. The attendance at the Rijeka Carnival implies that the individual arrival is dominant ( $88.6 \%$ of respondents), with the duration of visit between 1-3 days. Organized arrivals to the Rijeka Carnival are extremely small, which leaves additional space for the tourist animation programs and attracting new visitors. The entertainment is the primary motive of the visitors to the city of Rijeka (45.6\%), while the primary motive for attending the Rijeka Carnival is the recommendation of the acquaintance $(37.6 \%)$ and the image of a tourist event $(25.4 \%)$. In addition to this, it is evident that the city of Rijeka attracts visitors with cultural heritage, namely, $15.67 \%$ of respondents came to the city of Rijeka motivated by the elements of the heritage. The image of the destination attracted $25.36 \%$ of visitors, while the desire to learn and get acquainted with the heritage was a motive for visits of $18.23 \%$ visitors.

Table 1: Getting informed about the Rijeka Carnival

\begin{tabular}{|l|l|c|c|}
\hline \multicolumn{1}{|l|}{} & $\mathbf{N}$ & $\mathbf{( \% )}$ \\
\hline \multirow{4}{*}{$\begin{array}{l}\text { I learned about the } \\
\text { Rijeka Carnival } \\
\text { thanks to the... }\end{array}$} & Internet & 133 & $37.9 \%$ \\
\cline { 2 - 4 } & Newspapers & 0 & $0.0 \%$ \\
\cline { 2 - 4 } & TV & 50 & $14.2 \%$ \\
\cline { 2 - 4 } & Radio & 0 & $0.0 \%$ \\
\cline { 2 - 4 } & Leaflets and posters & 64 & $18.2 \%$ \\
\cline { 2 - 4 } & Local touristic organization & 1 & $0.3 \%$ \\
\cline { 2 - 4 } & Acquaintance's recommendation & 76 & $21.7 \%$ \\
\cline { 2 - 4 } & Local people's recommendation & 26 & $0.3 \%$ \\
\cline { 2 - 4 } & Other & 351 & $100.0 \%$ \\
\cline { 2 - 4 } & Total & & \\
\hline
\end{tabular}

Source: Authors' research

Table 1 shows the answers of the respondents' to the question of finding out about the Rijeka Carnival. The majority of respondents find out about the carnival from the Internet $(37.9 \%)$, recommendations from acquaintances $(21.7 \%)$, leaflets and posters $(18.2 \%)$. The above hypothesis $\mathrm{H} 3$ has been confirmed which points to the need for further management's investment for events by the development of modern web and mobile facilities and applications. 
ToSEE - Tourism in Southern and Eastern Europe, Vol. 5, pp. 249-262, 2019 D. Drpić, Z. Zadel, M. Obralić: MANAGING DEVELOPMENT OF EVENT TOURISM OFFER BASED ...

Table 2: Assessment of the satisfaction of the respondents with the elements of Rijeka carnival offer

\begin{tabular}{|c|c|c|c|c|}
\hline Groups & $\begin{array}{l}\text { Elements that impact the } \\
\text { level of the visitors' } \\
\text { satisfaction to a tourist event }\end{array}$ & $\begin{array}{l}\text { Average rating } \\
\text { of respondents' } \\
\text { satisfaction }\end{array}$ & SD & $\begin{array}{l}\text { Correlation } \\
\text { coefficient }\end{array}$ \\
\hline \multirow{7}{*}{$\begin{array}{l}\text { Recognition and } \\
\text { the quality of } \\
\text { facilities }\end{array}$} & $\begin{array}{c}\text { Recognition/ } \\
\text { Image (before arrival) }\end{array}$ & 3.37 & 2.69 & $79.82 \%$ \\
\hline & Access to the information & 3.20 & 2.41 & $75.31 \%$ \\
\hline & $\begin{array}{c}\text { Quality of promotional } \\
\text { material }\end{array}$ & 3.69 & 0.88 & $23.85 \%$ \\
\hline & Quality of event organization & 4.09 & 0.53 & $12.96 \%$ \\
\hline & The originality of the event & 3.74 & 0.74 & $19.79 \%$ \\
\hline & Interest & 4.07 & 0.61 & $14.99 \%$ \\
\hline & Quality of interpretation & 3.93 & 0.79 & $20.10 \%$ \\
\hline \multicolumn{2}{|c|}{ Recognition and the quality of facilities } & 3.72 & 0.84 & $22.58 \%$ \\
\hline \multirow{5}{*}{$\begin{array}{l}\text { Infrastructural } \\
\text { facilities }\end{array}$} & Transport accessibility & 4.94 & 0.32 & $6.48 \%$ \\
\hline & Safety & 4.81 & 0.40 & $8.32 \%$ \\
\hline & The tidiness of the site & 3.5 & 0.82 & $23.43 \%$ \\
\hline & $\begin{array}{c}\text { Cleanliness of sanitary } \\
\text { facilities }\end{array}$ & 2.01 & 1.80 & $89.55 \%$ \\
\hline & $\begin{array}{l}\text { The diversity of the } \\
\text { additional facilities }\end{array}$ & 2.05 & 1.67 & $81.46 \%$ \\
\hline \multicolumn{2}{|c|}{ Infrastructural facilities } & 3.46 & 0.62 & $17.92 \%$ \\
\hline \multirow{6}{*}{$\begin{array}{l}\text { Staff, prices, } \\
\text { facilities }\end{array}$} & $\begin{array}{l}\text { Working hours of hotels and } \\
\text { restaurants }\end{array}$ & 2.71 & 1.60 & $59.04 \%$ \\
\hline & $\begin{array}{c}\text { Prices of drinks, } \\
\text { accompanying facilities }\end{array}$ & 3.87 & 0.67 & $17.31 \%$ \\
\hline & Souvenirs & 2.36 & 0.78 & $33.05 \%$ \\
\hline & Kindness of staff & 3.89 & 0.52 & $13.37 \%$ \\
\hline & $\begin{array}{l}\text { Levels of knowledge and } \\
\text { professionalism of the staff }\end{array}$ & 3.88 & 0.53 & $13.66 \%$ \\
\hline & Value ratio for money & 3.84 & 0.37 & $9.64 \%$ \\
\hline \multicolumn{2}{|c|}{ Staff, prices, facilities } & 3.43 & 0.40 & $11.66 \%$ \\
\hline \multicolumn{2}{|c|}{ General Level of Visitors' Satisfaction } & 3.71 & 0.45 & $12.13 \%$ \\
\hline
\end{tabular}

Source: Authors' research

The overall level of recognition and quality of facilities and information about the Rijeka Festival was considered as satisfactory. The highest mean of the respondents' responses is observed for the quality of the event organization where the arithmetic mean of the respondent's response is 4.09 , the standard deviation is 0.53 . The mean average for the interest was 4.07 while the standard deviation was 0.61 . The lowest value of the arithmetic mean of the respondents' responses is recorded for the access to information (3.20) while the standard deviation is 2.41 . The recognition/image (before arrival) has the arithmetic mean for the respondent's response 3.37, while the standard deviation is 2.69. The overall level of satisfaction with the infrastructure is good (3.47), which contributes to the increase in overall satisfaction with a visit to the tourist event (3.84). 
ToSEE - Tourism in Southern and Eastern Europe, Vol. 5, pp. 249-262, 2019

D. Drpić, Z. Zadel, M. Obralić: MANAGING DEVELOPMENT OF EVENT TOURISM OFFER BASED ...

The highest value of the arithmetic mean of the respondents' answers is for the question traffic accessibility (4.94) with a standard deviation of 0.32 . The safety with the arithmetic mean of the respondent's response was 4.81 while the standard deviation was 0.40 . The mean value for the tidiness of the site is marginally very satisfactory 3.50 . The lowest value of the arithmetic means for the respondents' responses is observed for satisfaction with the cleanliness of sanitary facilities where the arithmetic mean of the respondents' response is 2.01 , while the standard deviation is 1.81 . Right after is the diversity of the accompanying facilitiess with the arithmetic mean of the respondent's response 2.05, while the standard deviation is 1.67 . The above indicates that more attention needs to be paid to the cleanliness and the numbers of sanitary facilities, as well as the place of the event. Besides, the existing program of the Rijeka Carnival should be supplemented with new facilitiess and events.

Visitors are very satisfied with the general level of staff service, prices, and quality of additional facilities. The highest value of the arithmetic mean of the respondents' responses is observed for the kindness of the staff (3.89), while the standard deviation of 0.52 . The lowest value of the arithmetic mean of respondents' responses is observed for the offer of souvenirs (2.36) with a standard deviation of 0.78 , the working hours of the hotels and restaurants also are not suitable for visitors (2.71). The above-mentioned points to the need for designing and making a traditional souvenir of the city of Rijeka, and the need to change the working time of the hotels and restaurants during the event. Visitors are satisfied with the levels of knowledge and professionalism of the staff (3.88). The value ratio for money is rated as satisfactory (3.84). The general level of satisfaction with the visit is observed with the arithmetic mean of 3.71, while the standard deviation is 0.45 . From the above, it follows that the visitors of the Rijeka Carnival are very satisfied with the visit to the Rijeka Carnival, thus the $\mathrm{H} 2$ hypothesis has been confirmed. Although the level of satisfaction of the visitors of the Rijeka Carnival is high, removing negative elements can result in its further increase, which will result in a higher level of consumption and economic benefits for the community.

Based on the conducted research by the authors, it is evident that the Rijeka Carnival has relatively good recognition on the tourist market, but in order to improve its competitive position, the management of events must pay special attention to:

- creating additional programs;

- $\quad$ ensuring a sufficient number of new sanitary facilities;

- maintenance of existing public sanitary facilities;

- the tidiness of the site of the event;

- designing and selling traditional souvenirs;

- maintaining longer working hours of the restaurants;

- the Rijeka Carnival as the top brand/product of the city of Rijeka;

- additional activities for the permanent improvement of the marketing-promotional mix.

Improving these shortcomings will contribute to the further strengthening of the recognition and competitiveness of the Rijeka Carnival events on the tourist market, as well as the entire Rijeka destination. These will contribute to the model of success of heritage-based tourism events, which is presented below. 
ToSEE - Tourism in Southern and Eastern Europe, Vol. 5, pp. 249-262, 2019

D. Drpić, Z. Zadel, M. Obralić: MANAGING DEVELOPMENT OF EVENT TOURISM OFFER BASED ...

\section{MODEL OF THE SUCCESSFUL TOURIST EVENTS BASED ON HERITAGE}

Based on the presented empirical results in the previous chapter, and in order to increase the level of satisfaction of visitors and achieve the competitiveness of the tourist offer, the authors emphasize the necessity of development of programs that will effectively take into account the value of the heritage for a community, which must be determined by evaluating the set of indicators. These indicators must be measurable and clearly positioned. Indicators can be set for the elements of material and non-material heritage, for the event itself or for the destination in which the event is held. Also, these indicators could be applied on all events which base their offer on the elements of non-material heritage with a goal of its preservation, improvement and sustainable tourist valorization. Indicators for evaluation of elements of tourist events based on heritage are (Drpić 2017):

- $\quad$ Heritage (material):

- Bearing capacity of the heritage;

- The economic, physical and emotional value of heritage;

- The state of the heritage and the level of protection of the site;

- The consequences of previous reconstruction and restoration of heritage;

- Models of financing the restoration and revitalization of heritage;

- Models of conversion of heritage;

- Possibilities for introducing it as a tourist product.

- Heritage (non-material)

- The number of elements of the non-material heritage in the destination/event;

- The economic and emotional value of the non-material heritage;

- A number of people who keep the non-material heritage "alive";

○ Models of financial support;

- Education programs (schools of folklore, songs, and crafts).

In order to approach the evaluation of material heritage properly it is necessary to determine its bearing capacity, which is possible by observing the existing number of visitors, but also based on the desired intensity of visits in the future, while in the nonmaterial heritage it is important to determine its level of preservation through the number of active speakers, singers, crafts and the like. The value of the inheritance is difficult to determine unambiguously because of its multiple manifestations, but it needs to be based on a set of assessments by the Destination Management, the local community and the professional community (restorer, conservation service, etc.).

The possibility of tourist valorization of the heritage will be influenced by the level of heritage preservation, as well as interventions on the object and site of heritage throughout history. Therefore, it is necessary that experts from the domain of heritage management determine the level of heritage originality as the basis for creating a plan for its economic conversion and reconstruction and future tourist realization. Based on the analyses that were carried out, it is necessary to choose the optimal method of financing the restoration, revitalization, and conservation of material heritage, as well as 
ToSEE - Tourism in Southern and Eastern Europe, Vol. 5, pp. 249-262, 2019

D. Drpić, Z. Zadel, M. Obralić: MANAGING DEVELOPMENT OF EVENT TOURISM OFFER BASED ...

the possibilities for ensuring the sustainability of the non-material heritage. Besides, it is necessary to determine models of incorporating heritage into a tourism product in order to preserve its authenticity and to create additional value for the tourism product. Creating synergies between events and destinations can be observed through:

- Event

- Compliance with existing development strategies;

- Market research;

- Sustainable event management;

- The originality of the event;

- The level of application of IT software solutions in all phases of the event;

- The diversity of the program;

- Models for event financing.

- Destination

- Preservation of the resource base;

- The wealth of material and non-material heritage;

- Introducing heritage as a touristic product.

Destination Management must value heritage as an important resource base, and the level of heritage representation must be in line with the wishes and needs of the local community and all factors in the destination. Steps that are necessary for sustainable management of the event and its success can be defined as:

○ Planning a heritage-based tourist event;

- Organization of a heritage-based tourist event;

- Implementation of a heritage-based tourist event;

- Measuring the success of a heritage based event;

- Reverse link;

- Corrective activities for removing observed shortcomings.

Each step must be based on the regular exchange of information between management and all the involved in the destination in order to achieve the excellence and long-term sustainability of events, and enable timely action in case of possible mismatches and implementation errors.

Below is a proposed model for the management of the Rijeka Carnival event in order to reduce the observed shortcomings and improve its performance. 
Figure 2: Proposed model for the management of the Rijeka Carnival

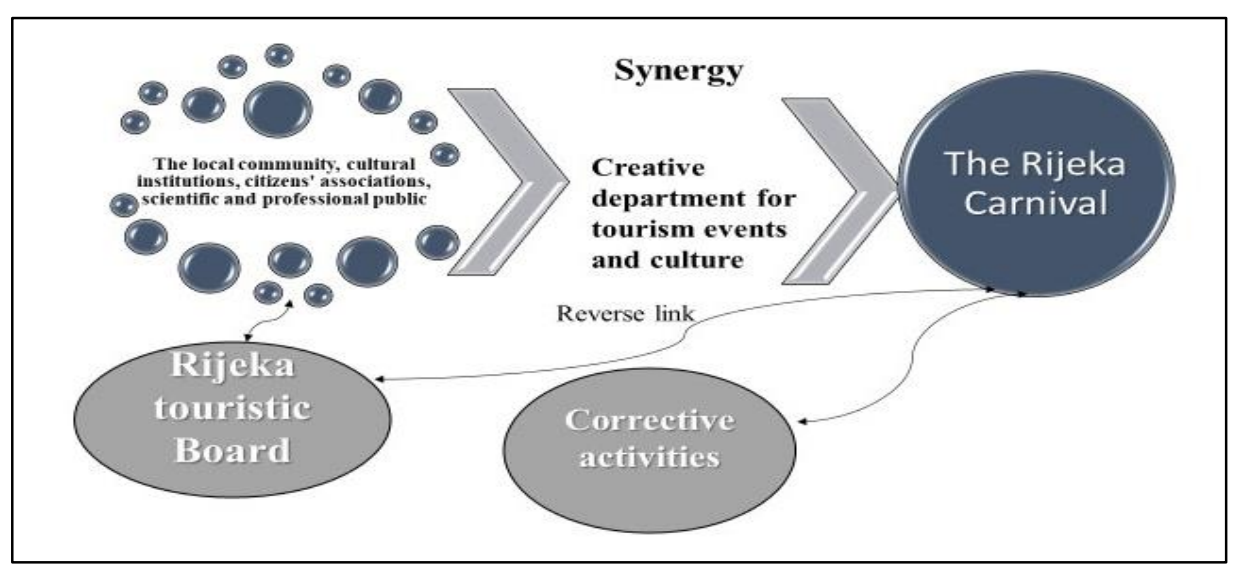

Source: Authors' research

The main trigger of the tourist event, its realization and improvement are the Rijeka Tourist Board. In order to improve the competitiveness of the event, it is necessary to conduct market research and user services regularly at the Rijeka Carnival event (participants, viewers, local community) and, based on their deliberations and organized public discussions it is necessary to create new facilities that will be provided by a special department that would design and create tourist events and in a way improve the heritage. After the events of the Rijeka Carnival, and based on the research carried out, a tourist community can initiate corrective actions in the short term and inform the interested participants accordingly. Acceleration of the process will enable the implementation of new technologies, mobile and web applications that will enable real-time feedback and enable more accurate recording of the number of visitors and users of services, which will contribute to easier development of the strategies for the development of the tourist event of the Rijeka Carnival in the future.

\section{CONCLUSION}

Sustainable event management can be achieved through the adoption of a local strategy for the sustainable management of events or the implementation of international quality standards, such as ISO20121 (International Organization for Standardization 2013). Sustainability must be the starting point of every Destination Management and must be persistent in the use of recycled and natural materials, reduced water, and electricity consumption, a sufficient amount of waste disposal sites, etc.

The diversity of programs, which must contain elements of national culture (gastronomic, musical, dance, etc.), will enable permanent recognition of events in the tourism market and the constant possibility of upgrading existing programs in order to increase the competitiveness of the tourist offer. The whole process of conducting evaluation through the application of standards and planning and the implementation of a tourist event must be based on the use of modern software solutions in order to respond 
ToSEE - Tourism in Southern and Eastern Europe, Vol. 5, pp. 249-262, 2019

D. Drpić, Z. Zadel, M. Obralić: MANAGING DEVELOPMENT OF EVENT TOURISM OFFER BASED ...

in optimal time frame with minimum errors and delays to face the challenges posed before the Destination Management at the time of making the decision to create a new heritage-based tourist event, especially when deciding about the sustainable financing for a tourist event, which is possible through sponsorship (businessmen, the tourist community, the local community, EU cohesion funds) or through the use of the Public Private Partnership/Public Civil Partnership model.

It is desirable that the funding model is based on multiple sources, in order to strengthen the economic viability of the event itself in the future. Based on the evaluation of the aforementioned indicators, Destination Management can make a decision to launch a heritage-based tourist event. The scientific contribution of the research is visible in the design of new the theoretical and applicable aspects of development and approach in evaluating a heritage-based tourism event that enables the creation of a wider picture for all the involved in the decision-making process, resulting in its applicable contribution. The limitations of the study are related to the difficulty of determining the number of visitors to the Rijeka Carnival and limiting the resources for the implementation of the research.

\section{REFERENCES}

Cibinskiene, A. (2012), "Impact evaluation of events as factors of city tourism competitiveness", Economics and Management, Vol. 17, No. 4, pp. 1333-1339 http://dx.doi.org/10.5755/j01.em.17.4.2997.

Crouch, G.I. (2011), "Destination Competitiveness: An Analysis of Determinant Attributes", Journal of Travel Research, Vol. 50, No.1, pp. 27-45 https://doi.org/10.1177\%2F0047287510362776.

Drpić, D. (2017), Turistički događaji temeljeni na baštini i konkurentnost turističke ponude [Tourist Events based on heritage and competitiveness of Tourist Offer], Doctoral Dissertation, Faculty of Tourism and Hospitality Management Opatija, Opatija, Republic of Croatia.

Drpić, D., Čosić, I and Milojica, V. (2017), "Contribution of events in strategic positioning of a destination on a tourist market: Case study of Kastafsko kulturno leto", In Proceedings of 17th Contemporary Trends in Tourism and Hospitality New Spaces in Cultural Tourism, September 1-2, 2017, pp. 172183, Novi Sad, Serbia.

Evans, N. Campnell D. and Stonehouse G. (2003), Strategic Management for Travel and Tourism, viewed 15 August 2017, http://www.sciencedirect.com/science/book/9780750648547.

Getz, D. (2008), "Event tourism: definition, evaluation and research", Tourism Management, Vol. 29, No. 3 , pp. 403-428 https://doi.org/10.1016/j.tourman.2007.07.017.

Getz, D. (2010), Event management \& Event Tourism, Cognizant Communication Corporation, New York, NY.

Getz, D. and Page, S. J. (2015), "Progress and prospects for event tourism research", Tourism Management, Vol. 52, pp. 593-631 http://dx.doi.org/10.1016/j.tourman.2015.03.007.

Hall, M. (1997), "Mega-events and their legacies", in Murphy, U.P. (Ed.), Quality Management in Urban Tourism, Wiley, Chichester, NY, pp. 75-87.

International Organization for Standardization (2013), ISO 20121 - Sustainable events, viewed 05 August 2017, https://www.iso.org/news/2013/09/Ref1789.html.

Institute for Tourism (2009), TOMAS 2008 Cultural Tourism, viewed 02 January 2019, http://www.iztzg.hr/UserFiles/File/novosti/2009.

Ivančić, I. (2015), Međuovisnost turističkih događaja u okruženju i uspješnost hotelijerstva [Interdependence of Tourist Events in surroundings and success of Hospitality], Doctoral Dissertation, Faculty of Tourism and Hospitality Management Opatija, Opatija, Republic of Croatia.

Jelinčić, A.D. (2009), "Cultural tourism: the state and perspectives of development in the Republic of Croatia", in Tišma, S. and Maleković, S. (Eds.), Zaštita okoliša i regionalni razvoj - iskustva i perspective [Protection of the Environment and regional development-experiences and perspectives], Institute for International Relations, Zagreb, Republic of Croatia, pp. 335-347. 
ToSEE - Tourism in Southern and Eastern Europe, Vol. 5, pp. 249-262, 2019

D. Drpić, Z. Zadel, M. Obralić: MANAGING DEVELOPMENT OF EVENT TOURISM OFFER BASED ...

Jelinčić, D.A. (2012), "Contemporary Identity: A Drive for Successful Cultural Tourism Management", in Ince, A. (Ed.), Cultural Policy and Management Yearbook (KPY) 2011, Istanbul Bilgi University Press, Istanbul, Republic of Turkey, pp. 66-72

Knešaurek, J. and Carić, H. (2018), Kulturni događaji $i$ manifestacije u turizmu [Cultural Events and Manifestations in Tourism], Institute for Tourism in Zagreb and Croatian Society of Music artists, Zagreb, Republic of Croatia.

Lozica, I. (1997), Hrvatski karnevali [Croatian Carnivals], Golden marketing, Zagreb, Republic of Croatia.

Milohnić, I. (2012), "How to increase the competitive advantages of small hotels: Measuring the effects of Public Relations", International Journal of Economic Perspectives, Vol. 6, No. 4, pp. 5-17.

Nakovski, D., Petrovska, J. and Milojica, V. "Events in function of increasing recognizability and competitiveness of a tourist destination (case study: Rijeka and Strumica carnival)", In Proceedings of International Scientific Conference ICONBEST, October 09-11, 2015, pp. 252-265, Skopje, Macedonia.

Ontario Ministry of Tourism, Culture and Sport, (2007), Guidelines: Survey Procedures for Tourism Economic Impact Assessments of Gated Events and Festivals, Research Resolutions \& Consulting Ltd, viewed 01 January 2019, http://www.mtc.gov.on.ca/en/research/resources/Guidelines_Econ Impact Gated_Events_2007.pdf.

Organization for Economic Co-operation and Development (OECD) (2009), The Impact of Culture on Tourism, viewed 20 January 2016, http://www.mlit.go.jp/kankocho/naratourismstatisticsweek/.

Porter, M.E. (1990), The Competitive Advantage of Nations, Free Press, New York, NY.

Rijeka Tourist Board (2018), Rijeka Carnival in numbers, viewed 15 October 2018, http://www.rijeckikarneval.hr/info/Rijeckikarnevalubrojkama.

Senge, P. (2001), Peta disciplina: Principi i praksa učeće organizacije [The Fifth Discipline: Princples and Practice of the Learning Organization], Mozaik knjiga, Zagreb, Republic of Croatia.

Stipanovic, C., Rudan, E. and Peršin, P. "Festival Tourism in the Repositioning of Croatian Tourism Destinations", In the Proceedings of 3rd International Scientific Conference Tourism in Southern and Eastern Europe, May 13-16, 2015, pp. 355-367. Opatija, Republic of Croatia.

Teece, J.D., Pisan, G. and Shuen, A. (1997), "Dynamic Capabilities and Strategic Management", Strategic Management Journal, Vol. 18, No 7, pp. 509-533, viewed 02 February 2019, https://www.business.illinois.edu/josephm/BA545_Fall\%202015/Teece,\%20Pisano\%20and\%20S huen\%20(1997).pdf.

Tourist Board of the city of Rijeka, (2013), Riječki karneval monografija [Rijeka Carnival Monography], Printera grupa, Zagreb, Republic of Croatia.

Tourist Board of the city of Rijeka, (2019), data acquired through e-mail.

UNESCO (2013), Convention for the Safeguarding of the Intangible Cultural Heritage, viewed 1 January, 2019, https://ich.unesco.org/en/convention

Zadel, Z. and Bogdan, S. (2013), "Economic impact of cultural tourism", UTMS Journal of Economics, Vol. 4, No. 3, pp. 355-367

Danijel Drpić, $\mathrm{PhD}$, Assistant

Polytechnic of Rijeka

Vukovarska ulica 58, 51000 Rijeka, Croatia

Phone: 099/267-9457

E-mail: ddrpic@veleri.hr

Zrinka Zadel, PhD, Associate Professor

University of Rijeka, Faculty of Tourism and Hospitality Management

Primorska 42, 51410 Opatija, Croatia

Phone: +385 51 294-183

E-mail: zrinkas@fthm.hr

Merdžana Obralić, PhD, Assistant Professor

University in Sarajevo, Faculty of Administration,

Igmanska 41 A, 71320 Vogošća, Sarajevo, Bosnia and Herzegovina

Phone: +387 33 553-835

E-mail: merdzana.obralic@fu.unsa.ba 